УДК 811.111'276.6

DOI https://doi.org/10.24919/2308-4863/44-3-38

\title{
Анна ХОМИК,
}

orcid.org/0000-0002-6574-2262

аспірант кафедри англійської філології та методики навчання англійської мови

Тернопільського начіонального педагогічного університету імені Володимира Гнатюка, асистент кафедри іноземних мов для природничих факультетів факультету іноземних мов Львівського Наџіонального університету імені Івана Франка (Львів, Украӥна) a.logvinova22@gmail.com

\section{РОЛЬ МЕТАКОГНІТИВНИХ, КОГНІТИВНИХ СТРАТЕГІЙ ТА СТРАТЕГІЙ ВИКОРИСТАННЯ ІНОЗЕМНОЇ МОВИ У ПРОЦЕСІ ФОРМУВАННЯ СТРАТЕГІЧНОЇ КОМПЕТЕНТНОСТІ МАЙБУТНІХ ІТ-ФАХІВЦІВ}

\begin{abstract}
Дослідження визначають компетентність як інтегративну якість особистості, яка трунтується на взаємозв'язку теоретичних знань, практичних умінь і мотивації, зумовлює готовність індивіда до виконання певної діяльності незалежно від контексту проблеми. У статті викладено структуру стратегічної компетентності, котра окрім знань, навичок, умінь і комунікативних стратегій містить навчальні стратегії, такі як метакогнітивні, когнітивні, соціальні стратегї та стратегї̈ оцінювання. Сформованість метакогнітивних стратегій забезпечує студентам здатність планувати, контролювати й оцінювати власну навчальну діяльність. Сформованість когнітивних стратегій забезпечує здатність оперування навчальним матеріалом, пошуку, сприйняття та обробки інформації. Сформованість соціальних стратегій забезпечує взаємодію з іншими учасниками навчального процесу й контроль за власними емоціями. До метакогнітивних стратегій науковці відносять: стратегї концентрації на процесі навчання чи певних иілях; стратегї планування процесу навчання (реалізуються тактиками визначення циілей навчання, виконання певного завдання); вибір і варіювання стилю навчання; пошук можливостей для самостійної практики; стратегії контролю за розумінням виконання завдань. Стратегії самооцінювання результатів навчальної діяльності реалізуються тактиками виконання тестових завдань і перевірки правильності їх виконання. Опанування майбутніми IT-фахівиями стратегічної компетентності в усному англомовному професійно орієнтованому спілкуванні передбачає використання навчальних, а саме метакогнітивних і когнітивних стратегій, а також стратегій використання англійської мови за професійним спрямуванням. Метакогнітивні стратегії забезпечують регулювання, планування процесу навчання, а когнітивні-розвиток навичок та умінь у продуктивних і рецептивних видах мовленнєвої діяльності, а тому мають вагомий вплив на сформованість стратегічної компетентності в майбутнього IT-фахівця загалом.
\end{abstract}

Ключові слова: стратегічна компетентність, метакогнітивні стратегіï, когнітивні стратегії, комунікативна компетентність.

Anna KHOMYK,
orcid.org/0000-0002-6574-2262
Assistant at the Department of Foreign Languages for Natural sciences
Ivan Franko National University of Lviv,
Assistant of the Department of Foreign Languages for the Faculty of Natural Sciences of the Faculty
of Foreign Languages
Ternopil Volodymyr Hnatiuk National Pedagogical University
(Lviv, Ukraine) a.logvinova22@gmail.com

\section{ROLE OF METACOGNITIVE, COGNITIVE STRATEGIES AND STRATEGIES OF FOREIGN LANGUAGE USE IN THE PROCESS OF FORMATING STRATEGIC COMPETENCE AMONG FUTURE IT PROFESSIONALS}

Research defines competence as an integrative quality of personality, which is based on the relationship of theoretical knowledge, practical skills and motivation, determines the readiness of the individual to perform certain activities, regardless of the context of the problem. The article highlights the structure of strategic competence, which in addition to knowledge, skills, abilities and communication strategies includes learning strategies such as metacognitive strategies, cognitive strategies, social strategies and assessment strategies. The formation of metacognitive strategies provides students with the ability to plan, monitor and evaluate their own learning activities. The formation of cognitive strategies provides the ability to operate the educational material, search, perception and processing of information. The formation of social strategies provides interaction with other participants in the learning process and control over their own emotions. 
Metacognitive strategies include: strategies for concentrating on the learning process or specific goals, strategies for planning the learning process (implemented by tactics for defining learning goals, performing a specific task), choosing and varying learning style, finding opportunities for independent practice, strategies for monitoring understanding of tasks. The acquisition of strategic competence by future IT specialists in oral English-speaking professionally oriented communication involves the use of educational, namely metacognitive and cognitive strategies, as well as strategies for the use of English for professional purposes. Metacognitive strategies provide regulation, planning of the learning process, and cognitive provide the development of skills and abilities during oral activity, and therefore have a significant impact on the formation of strategic competence of the future IT specialist in general.

Key words: strategic competence, metacognitive strategies, cognitive strategies, communicative competence.

Постановка проблеми. Однією 3 найвагоміших складових частин професійної компетентності майбутніх ІT-фахівців, які забезпечують ефективність їх професійно орієнтованого спілкування, науковці правомірно вважають стратегічну компетентність. Інваріантними компонентами стратегічної компетентності ІT-фахівців є відповідні стратегії: комунікативні, навчальні, стратегії використання мови.

Аналіз досліджень. Стратегії, що входять до структури стратегічної компетентності, вивчали й класифікували Л. Бахман (L. Bachman), I. Дроздова, I. Задорожна, Дж. O’Маллі (J. O’Malley), О. Мисечко, А. Шамо (А. Chamot), А. Щукін та інші науковці. Попри значну кількість наукових розвідок, присвячених аналізу навчальних стратегій, недослідженою залишається проблема вживання навчальних стратегій і стратегій використання іноземної мови в процесі формування стратегічної компетентності майбутніх ІТ-фахівців.

Мета статті - виокремити й проаналізувати метакогнітивні, когнітивні стратегії та стратегії використання іноземної мови (англійської), що вживаються в процесі формування стратегічної компетентності майбутніх IT-фахівців.

Виклад основного матеріалу. На основі аналізу наукової літератури (Задорожна, 2012: 285), що викладає структуру стратегічної компетентності, вважаємо, що окрім відповідних знань, навичок, умінь і комунікативних стратегій до такої структури належать навчальні стратегії (метакогнітивні й когнітивні) і стратегії використання іноземної мови в різних видах мовленнєвої діяльності.

Л. Бахман, окреслюючи коло стратегій, що складають структуру стратегічної компетентності, окрім комунікативних стратегій у структурі стратегічної компетентності визначає метакогнітивні стратегії, когнітивні стратегії, стратегії виконання та стратегії оцінювання. На думку вченого, стратегічна компетентність повинна охоплювати всі аспекти виконання комунікативних завдань (Bachman, 1990: 107).

Оскільки формування стратегічної компетентності в усному англомовному професійно орієн- тованому спілкуванні в майбутніх IT-фахівців відбувається в процесі вивчення ними іноземної мови за професійним спрямуванням, вважаємо за доцільне звернутися до дослідження Дж. О’Маллі (J. O’Malley J.) та А. Шамо (A. Chamot), які окреслюють 24 стратегії вивчення іноземної мови й класифікують їх на три категорії: метакогнітивні стратегії, когнітивні стратегії та соціальні / афективні стратегіï (O’Malley, Chamot, 1990: 265). Сформованість метакогнітивних стратегій забезпечує студентам здатність планувати, контролювати й оцінювати власну навчальну діяльність. Сформованість когнітивних стратегій, до яких науковці відносять також мнемічні й компенсаторні стратегії, виокремлені Р. Оксфорд (Oxford, 1990: 18-21), забезпечує здатність оперування навчальним матеріалом, пошуку, сприйняття та обробки інформації. Сформованість соціальних / афективних стратегій забезпечує взаємодію 3 іншими учасниками навчального процесу й контроль за власними емоціями (O'Malley, Chamot, 1990: 265).

У Загальноєвропейських рекомендаціях з мовної освіти навчальні стратегії розглядаються як певним чином організована, цілеспрямована й керована лінія поведінки, обрана індивідом для виконання завдання, яке він собі поставив чи з яким йому довелося зіштовхнутися (Ніколаєва, 2003: 273).

А. Щукін визначає навчальні стратегії як певні комбінації інтелектуальних прийомів і зусиль, що застосовуються студентами 3 метою розуміння, запам'ятовування та використання знань про систему мови, а також формування мовленнєвих навичок та умінь (Щукин, 2007: 746).

Категорія метакогнітивних стратегій спрямована на регулювання процесу навчання. До метакогнітивних стратегій науковці відносять: стратегії концентрації на процесі навчання / певному завданні / певних цілях (реалізуються тактиками концентрації уваги в конкретні проміжки часу, усування перешкод та іншими); стратегії планування процесу навчання (реалізуються тактиками визначення цілей навчання, виконання певного завдання, вибору й варіювання стилю навчання, пошуку можливостей для самостійної практики, 
використання ресурсів, ведення нотаток, записів); стратегії контролю за розумінням / продукуванням мовлення / ходом виконання завдань і стратегії самооцінювання результатів навчальної діяльності, виконання завдань, рівня сформованості цільової компетентності (реалізуються тактиками виконання тестових та інших завдань і перевірки правильності їх виконання).

Категорія когнітивних стратегій спрямована на забезпечення результативності процесу навчання та виконання конкретних завдань. До когнітивних стратегій належать: стратегії запам'ятовування (реалізуються тактиками вивчення правил, створення ментальних зв'язків (групування, створення асоціативних зв'язків), використання контексту, уяви, опор (створення семантичних карт, граф, інтелект-мап), ключових слів, повторення); стратегії розвитку навичок та умінь у продуктивних і рецептивних видах мовленнєвої діяльності (реалізуються тактиками використання мовленнєвих зразків, узагальнення, виділення основного, перекладу, перетворення, вправляння в типових і проблемних комунікативних ситуаціях (особливо ефективне з використанням візуальних опор, засобів занурення та інших ресурсів), визначення труднощів та іншими).

I. Задорожна до прямих когнітивних стратегій опанування іноземної мови відносить: стратегії запам'ятовування, що реалізовуються за допомогою створення ментальних зв'язків, опор та іншого, стратегії активізації мовних засобів, мовленнєвих моделей, стратегії систематизації, виділення основного, узагальнення, визначення когнітивних труднощів (Задорожна, 2012: 770).

Щодо стратегій використання іноземної мови в різних видах мовленнєвої діяльності, у контексті тематики нашого дослідження акцентуємо на стратегіях використання англійської мови за професійним спрямуванням у говорінні й аудіюванні. Так, до стратегій використання англійської мови за професійним спрямуванням у говорінні й аудіюванні з урахуванням результатів досліджень науковців відносимо:

- стратегії використання англійської мови за професійним спрямуванням під час продукування та відтворення мовлення (Дроздова, 2009: 186): тактики активізації внутрішніх ресурсів; вибору стилю, структури дискурсу; уточнення комунікативного наміру; розширення завдання (Мисечко, 2004: 174); перевірки адекватності й правильності використаних лінгвістичних засобів; активізації змістових замін; формування динамічного концепту висловлювань (Дроздова, 2009: 190);

- стратегії використання мовленнєвих кліше; стратегії моніторингу успішності усного висловлю- вання за допомогою жестів, міміки, дій співрозмовника; стратегії аналізу аудіозапису власного висловлювання чи діалогу;

- стратегії використання англійської мови за професійним спрямуванням під час аудіювання (Дроздова, 2009: 191): тактики активізації лінгвосоціокультурних і лінгвістичних знань; передбачення організаційної структури й змісту інформації; ідентифікації отриманої лінгвістичної та екстралінгвістичної інформації (Мисечко, 2004: 175); пошуку контекстуальних і внутрішньомовних опор (Дроздова, 2009: 191);

- інтерактивні стратегії використання англійської мови за професійним спрямуванням: тактики активізації варіантів розгортання комунікативної взаємодії; побудови гіпотези щодо комунікативного наміру співрозмовника в контексті типової чи проблемної комунікативної ситуації; перевірки гіпотези щодо комунікативного наміру співрозмовника в контексті типової чи проблемної комунікативної ситуації; визначення прогалин у системі лінгвістичних знань, предметних знань співрозмовників чи прогалин в інформації, якою вони володіють; урахування потреб співрозмовників; (Мисечко, 2004: 177); передачі черги співрозмовникові; використання заповнювачів мовчання; досягнення взаєморозуміння; звертання до співрозмовника; моніторингу відповідності взаємодії поставленій задачі; моніторингу успішності взаємодії; розв'язання непорозуміння та залагодження конфліктної ситуації; відновлення спілкування (Ніколаєва, 2003: 273).

Як витікає 3 нашого аналізу, окремі науковці відносять компенсаторні, соціальні й афективні стратегії до навчальних стратегій (Oxford, 1990; O'Malley, Chamot, 1990: 18-21). На основі результатів досліджень I. Задорожної (Задорожна, 2012: 285) ми відносимо компенсаторні, соціальні й афективні стратегії до комунікативних стратегій.

В умовах незначної кількості аудиторних годин для вивчення іноземної мови за професійним спрямуванням студентами закладів вищої освіти особливої актуальності набуває самостійна робота, яка дозволяє оптимізувати освітній процес шляхом розширення часових рамок і сформувати в здобувачів вищої освіти, у тому числі в майбутніх IT-фахівців, здатність самостійно навчатися та в такому процесі накопичувати відповідні знання, розвивати навички й уміння, формувати здатності й компетентності (Котловський, 2017: 253). Як для аудиторного навчання, так і для навчання в умовах самостійної роботи, спрямованого на формування стратегічної компетентності в усному іншомовному професійно орієнтованому спілкуванні, доцільно використовувати такі стратегії 
навчання, як перегляд автентичних фільмів задля привернення уваги студентів до форм мовленнєвих актів і соціолінгвістичних змінних, в умовах яких відбуваються мовленнєві акти.

Здійснений аналіз дозволяє виокремити низку навчальних стратегій і стратегій використання майбутніми IT-фахівцями англійської мови за професійним спрямуванням в говорінні й аудіюванні. Так, до навчальних стратегій опанування майбутніми IT-фахівцями стратегічної компетентності в усному англомовному професійно орієнтованому спілкуванні відносимо:

- метакогнітивні стратегії регулювання процесу навчання;

- когнітивні стратегії забезпечення результативності процесу навчання та виконання конкретних завдань.

До стратегій використання майбутніми IT-фахівцями англійської мови за професійним спрямуванням у говорінні й аудіюванні належать:

- стратегії використання англійської мови за професійним спрямуванням під час продукування та відтворення мовлення;

- стратегії використання англійської мови за професійним спрямуванням під час аудіювання;

- інтерактивні стратегії використання англійської мови за професійним спрямуванням.

Узагальнення, класифікація та систематизація положень проаналізованих наукових розвідок дозволяє представити арсенал метакогнітивних, когнітивних стратегій і стратегій використання мови - складових частин стра- тегічної компетентності майбутніх ІТ-фахівців в усному англомовному професійно орієнтованому спілкуванні й тактик їх реалізації - у формі таблиці (табл. 1).

На визначених навчальних стратегіях і тактиках, а також стратегіях і тактиках використання англійської мови за професійним спрямуванням складових частинах стратегічної компетентності майбутніх IT-фахівців - концентруватимемось у процесі розроблення методики формування в таких фахівців цільової компетентності, зокрема відбору методів і засобів навчання та укладання підсистеми вправ і завдань.

Висновки. Опанування майбутніми IT-фахівцями стратегічної компетентності в усному англомовному професійно орієнтованому спілкуванні передбачає використання навчальних, а саме метакогнітивних і когнітивних стратегій, а також стратегій використання англійської мови за професійним спрямуванням. Метакогнітивні стратегії забезпечують регулювання, планування процесу навчання, контроль за мовленням, самооцінювання результатів навчальної діяльності. Когнітивні стратегії забезпечують розвиток навичок та умінь у продуктивних і рецептивних видах мовленнєвої діяльності. Виокремлення тактик вищезгаданих стратегій сприяє ефективному опануванню майбутніми IT-фахівцями стратегічної компетентності.

Перспективи подальших досліджень вбачаємо в обгрунтуванні етапів формування стратегічної компетентності майбутніх IT-фахівців.

Таблиця 1

\section{Метакогнітивні, когнітивні стратегії та стратегії використання мови - складові частини} стратегічної компетентності майбутніх ІT-фахівців

\begin{tabular}{|c|c|c|}
\hline Групи стратегій & Стратегіï & Тактики реалізації стратегій \\
\hline 1 & 2 & 3 \\
\hline $\begin{array}{l}\text { Навчальні стратегії } \\
\text { опанування } \\
\text { майбутніми } \\
\text { IТ-фахівцями } \\
\text { стратегічної } \\
\text { компетентності } \\
\text { в усному } \\
\text { англомовному } \\
\text { професійно } \\
\text { орієнтованому } \\
\text { спілкуванні }\end{array}$ & $\begin{array}{l}\text { - метакогнітивні стратегії: концентрації } \\
\text { на процесі навчання, певному завданні, } \\
\text { певних цілях; регулювання процесу } \\
\text { навчання; планування процесу } \\
\text { навчання; контролю за розумінням } \\
\text { / продукуванням мовлення / ходом } \\
\text { виконання завдань; самооцінювання } \\
\text { результатів навчальної діяльності, } \\
\text { виконання завдань, рівня сформованості } \\
\text { цільової компетентності; } \\
\text { - когнітивні стратегії: запам’ятовування, } \\
\text { розвитку навичок та умінь у } \\
\text { продуктивних і рецептивних видах } \\
\text { мовленнєвої діяльності }\end{array}$ & $\begin{array}{l}\text { Визначення цілей навчання, концентрації } \\
\text { уваги в певні проміжки часу, усування } \\
\text { перешкод, виконання певного завдання, } \\
\text { вибору й варіювання стилю навчання, пошуку } \\
\text { можливостей для самостійної практики, } \\
\text { використання ресурсів, ведення нотаток, записів, } \\
\text { виконання та самостійної перевірки тестових } \\
\text { завдань та інше; вивчення правил, створення } \\
\text { ментальних зв’язків (групування, створення } \\
\text { асоціативних зв’язків), використання контексту, } \\
\text { уяви, опор (створення семантичних карт, граф, } \\
\text { інтелект-мап), ключових слів, повторення, } \\
\text { мовленнєвих зразків, узагальнення, виділення } \\
\text { основного, перекладу, перетворення, вправляння } \\
\text { в типових і проблемних комунікативних } \\
\text { ситуаціях (особливо ефективне з використання } \\
\text { візуальних опор, засобів занурення та інших } \\
\text { ресурсів), визначення труднощів та інші). }\end{array}$ \\
\hline
\end{tabular}


Продовження таблиці 1

\begin{tabular}{|c|c|c|}
\hline 1 & 2 & 3 \\
\hline $\begin{array}{l}\text { Стратегії } \\
\text { використання } \\
\text { майбутніми } \\
\text { IT-фахівцями } \\
\text { англійської мови } \\
\text { за професійним } \\
\text { спрямуванням } \\
\text { у говорінні й } \\
\text { аудіюванні }\end{array}$ & $\begin{array}{l}\text { - використання англійської мови за } \\
\text { професійним спрямуванням під час } \\
\text { продукування та відтворення мовлення; } \\
\text { - використання англійської мови за } \\
\text { професійним спрямуванням під час } \\
\text { аудіювання; } \\
\text { - інтерактивні стратегії використання } \\
\text { англійської мови за професійним } \\
\text { спрямуванням }\end{array}$ & $\begin{array}{l}\text { Активізації внутрішніх ресурсів, вибору стилю, } \\
\text { структури дискурсу, уточнення комунікативного } \\
\text { наміру, перевірки адекватності й правильності } \\
\text { використаних лінгвістичних засобів, } \\
\text { розширення завдання, активізації змістових } \\
\text { замін, формування динамічного концепту } \\
\text { висловлювань, використання мовленнєвих } \\
\text { кліше, моніторингу успішності усного } \\
\text { висловлювання за допомогою невербальних } \\
\text { засобів: жестів, міміки, дій співрозмовника; } \\
\text { аналізу аудіозапису власного висловлювання } \\
\text { чи діалогу, активізації лінгвосоціокультурних і } \\
\text { лінгвістичних знань, організаційної структури } \\
\text { й змісту інформації, ідентифікації отриманої } \\
\text { лінгвістичної та екстралінгвістичної інформації, } \\
\text { пошуку контекстуальних і внутрішньомовних } \\
\text { опор, активізації варіантів розгортання } \\
\text { комунікативної взаємодії, побудови гіпотези } \\
\text { щодо комунікативного наміру співрозмовника } \\
\text { в контексті типової чи проблемної } \\
\text { комунікативної ситуації, перевірки гіпотези } \\
\text { щодо комунікативного наміру співрозмовника в } \\
\text { контексті типової чи проблемної комунікативної } \\
\text { ситуації, визначення прогалин у системі } \\
\text { лінгвістичних знань, предметних знань } \\
\text { співрозмовників чи в інформації, якою вони } \\
\text { володіють, урахування потреб співрозмовників, } \\
\text { передачі черги співрозмовникові, використання } \\
\text { заповнювачів мовчання, досягнення } \\
\text { взаєморозуміння, звертання до співрозмовника, } \\
\text { моніторингу відповідності взаємодії } \\
\text { поставленій задачі, моніторингу успішності } \\
\text { взаємодії, розв’язання непорозуміння та } \\
\text { залагодження конфліктної ситуації, відновлення } \\
\text { спілкування }\end{array}$ \\
\hline
\end{tabular}

\section{СПИСОК ВИКОРИСТАНИХ ДЖЕРЕЛ}

1. Дроздова I. П. Стратегії оволодіння мовою як запорука успішного навчання професійного мовлення. Педагогічні науки: теорія, історія, інноваційні технології. 2009. № 1. С. 186-193.

2. Загальноєвропейські Рекомендації з мовної освіти: вивчення, викладання, оцінювання / пер. 3 англ. О. М. Шерстюк ; наук. ред. укр. вид-ня С. Ю. Ніколаєва. Київ : Ленвіт, 2003. 273 с.

3. Задорожна I. П. Теоретико-методичні засади організації самостійної роботи майбутніх учителів $з$ оволодіння англомовною комунікативною компетенцією : дис. ... д-ра пед. наук : 13.00 .02 ; Київський національний лінгвістичний університет. Київ, 2012. 770 с.

4. Котловський А. М. Формування англомовної лексико-граматичної компетентності в говорінні майбутніх економістів у процесі самостійної роботи : дис. ... канд.. пед. наук : 13.00 .02 ; Тернопільській педагогічний університет. Тернопіль, 2017. 253 с.

5. Мисечко О. С. Поняття стратегічної компетенції у змісті сучасної професійної підготовки вчителя іноземної мови у ВНЗ. Вісник Житомирського державного університету імені Івана Франка. 2004. Вип. 19. С. $174-178$.

6. Щукин А. Н. Лингводидактический энциклопедический словарь : более 2000 слов. Москва : Астрель : АСТ : Хранитель, 2007. 746 с.

7. Bachman L. Fundamental considerations in language testing. Oxford : Oxford University Press, 1990. 400 p.

8. O’Malley J. M., Chamot A. U. Learning Strategies in Second Language Acquisition. Cambridge : Cambridge University Press, 1990. 265 p.

9. Oxford R. L. Language Learning Strategies. Boston : Heinle and Heinle Publishers, 1990. 343 p.

\section{REFERENCES}

1. Drozdova I. P. Stratehii ovolodinnia movoiu yak zaporuka uspishnoho navchannia profesiinoho movlennia. Pedahohichni nauky: teoriia, istoriia, innovatsiini tekhnolohii. [Language acquisition strategies as a guarantee of successful professional speech training. Pedagogical sciences: theory, history, innovative technologies], 2009, Nr. 1, pp. 186-193 [in Ukrainian]. 
2. Nikolaieva S. Yu.. Zahalnoievropeiski Rekomendatsii z movnoi osvity: vyvchennia, vykladannia, otsiniuvannia [Pan-European Recommendations on language education: study, teaching, assessment] translated by Sherstiuk, Lenvit, 2003, 273 p. [in Ukrainian].

3. Zadorozhna I. P. Teoretyko-metodychni zasady orhanizatsii samostiinoi roboty maibutnikh uchyteliv z ovolodinnia anhlomovnoiu komunikatyvnoiu kompetentsiieiu [Theoretical and methodical bases of the organization of independent work of future teachers on mastering of English communicative competence] Kyiv, 2012, 770 p. [in Ukrainian].

4. Kotlovskyi A. M. Formuvannia anhlomovnoi leksyko-hramatychnoi kompetentnosti v hovorinni maibutnikh ekonomistiv u protsesi samostiinoi roboty [Formation of English lexical and grammatical competence in the speech of future economists in the process of independent work] Ternopil, 2017, 253 p. [in Ukrainian].

5. Mysechko O. Ye. Poniattia stratehichnoi kompetentsii u zmisti suchasnoi profesiinoi pidhotovky vchytelia inozemnoi movy u VNZ [The concept of strategic competence in the content of modern professional training of foreign language teachers in higher education] magazine, 2004, Nr 19, pp. 174-178 [in Ukrainian].

6. Shchukyn A. N. Lingvodidakticheskiy entsiklopedicheskiy slovar: bolee 2000 slov. [Linguodidactic encyclopedic dictionary: more than 2000 words] 2007, 746 p. [in Russian].

7. Bachman L. Fundamentalni mirkuvannia pid chas movnoho testuvannia [Fundamental considerations in language testing] Oxford University Press, 1990, 400 p.

8. O’Malley J. M., Chamot A. U. Navchalni stratehii pid chas vyvchennia druhoi inozemnoi movy [Learning Strategies in Second Language Acquisition] Cambridge University Press, 1990, 265 p.

9. Oxford R. L. Stratehii vyvchennia movy [Language Learning Strategies] Boston : Heinle and Heinle Publishers, 1990, 343 p. 